\title{
Hepatitis B Reactivation During Immunosuppressive Therapy or Cancer Chemotherapy, Management, and Prevention: A Comprehensive Review
}

\author{
Soheil Tavakolpour, ${ }^{1}$ Seyed Moayed Alavian,, ${ }^{1, *}$ and Shahnaz Sali ${ }^{2}$ \\ ${ }^{1}$ Baqiyatallah Research Center for Gastroenterology and Liver Diseases, Baqyiatallah University of Medical Sciences, Tehran, IR Iran \\ ${ }^{2}$ Infectious Diseases and Tropical Medicine Research Center, Shahid Beheshti University of Medical Sciences, Tehran, IR Iran \\ "Corresponding author: Seyed Moayed Alavian, Baqiyatallah Research Center for Gastroenterology and Liver Diseases, Baqyiatallah University of Medical Sciences, Tehran, IR \\ Iran. Tel/Fax:+98-2181264070, E-mail: Alavian@thc.ir
}

Received 2015 December 26; Revised 2016 January 17; Accepted 2016 January 27.

\begin{abstract}
Context: Due to the close relationship between the immune system and the hepatitis B virus (HBV) replication, it is essential to monitor patients with current or past HBV infection under any type of immunosuppression. Cancer chemotherapy, immunosuppressive therapies in autoimmune diseases, and immunosuppression in solid organ and stem cell transplant recipients are the major reasons for hepatitis B virus reactivation $(\mathrm{HBVr})$. In this review, the challenges associated with $\mathrm{HBVr}$ are discussed according to the latest studies and guidelines. We also discuss the role of treatments with different risks, including anti-CD20 agents, tumor necrosis factor-alpha (TNF- $\alpha$ ) inhibitors, and other common immunosuppressive agents in various conditions.

Evidence Acquisition: Through an electronic search of the PubMed, Google Scholar, and Scopus databases, we selected the studies associated with $\mathrm{HBVr}$ in different conditions. The most recent recommendations were collected in order to reach a consensus on how to manage patients at risk of HBVr.

Results: It was found that the positive hepatitis B surface antigen (HBsAg), the high baseline HBV DNA level, the positive hepatitis B virus e antigen (HBeAg), and an absent or low hepatitis B surface antibody (HBsAb) titer prior to starting treatment are the most important viral risk factors. Furthermore, rituximab, anthracycline, and different types of TNF- $\alpha$ inhibitors were identified as the high-risk therapies. By analyzing the efficiency of prophylaxis on the prevention of HBVr, it was concluded that those with a high risk of antiviral resistance should not be used in long-term immunosuppressants. Receiving HBV antiviral agents at the commencement of immunosuppressant therapy or chemotherapy was demonstrated to be effective in decreasing the risk of HBVr. Prophylaxis could also be initiated before the start of therapy. For most immune suppressive regimes, antiviral therapy should be kept up for at least 6 months after the cessation of immunosuppressive drugs. However, the optimal time of prophylaxis keeping should be increased in cases associated with rituximab or hematopoietic stem cell transplants. According to the latest studies and guidelines from different bodies, recommendations regarding screening, monitoring, and management of HBVr are outlined.

Conclusions: Identification of patients at the risk of HBVr before immunosuppressive therapy is an undeniable part of treatment. Starting the antiviral therapy, based on the type of immunosuppressive drugs and the underlying disease, could lead to better management of disease.
\end{abstract}

Keywords: Hepatitis B Virus, Reactivation, Immunosuppression, Rituximab, Prophylaxis

\section{Context}

It is estimated that more than 2 billion of the world's population have experienced the hepatitis B virus (HBV) infection during their lifetime, and there are approximately 350 million patients with chronic hepatitis B (CHB) (1). Generally, patients with HBV can be divided into four distinct phases: (i) the immunotolerant phase; (ii) the immune active phase; (iii) the low-replication phase; and (iv) the recovery phase. Everyone who has been exposed to HBV infection is in danger of the infection reactivating. In patients with $\mathrm{CHB}$ who are under immunosuppressive therapy, HBV replication will increase dramatically due to im- paired cellular and humoral immunity. Following the termination of immunosuppressants, reconstitution of the host immunity results in a serious flare-up of the disease due to cytotoxic activity of the immune cells. This occurrence is considered to be the reactivation of HBV after an increase in $\mathrm{HBV}$ replication because of impaired immune responses. HBV reactivation (HBVr) can also occur after immunosuppressive chemotherapy in patients with occult HBV infection (OBI) (HBVDNA and the antibodies to hepatitis $B$ core antigens are present without detectable hepatitis B surface antigens) and resolved HBV (the presence of HBV antibodies without HBV DNA and hepatitis B surface anti- 
gens). In hepatitis B surface antigen (HBsAg) carriers, immunosuppressant agents that induce weakened immune responses lead to an increase in viral replication as well as removing the immune system balance. This results in the growth of viral replication, which may be followed by rising liver enzymes, liver disease, and even death. Furthermore, HBVr causes premature termination of immunosuppressive chemotherapy or a delay in treatment schedules (2). In individuals who cleared HBsAg, including occult or resolved patients, covalently closed circular DNA (cccDNA) can persist. In conditions with declined antiviral immune responses, such as immunosuppressive therapy or chemotherapy, viral core particles that migrated to the hepatocyte nucleus at the time of infection can be repaired to form the cccDNA and rebuild the viral replication cycle. HBV cccDNA acts as the template for viral messenger RNA (mRNA) transcription. mRNA is then translated in the cytoplasm to produce the viral surface, core, polymerase, and $\mathrm{X}$ proteins (3). In addition to immunosuppressive therapy or chemotherapy, HBVr may happen spontaneously in the presence of virus mutation.

Immunosuppressant therapy can be performed by multiple agents. Some of them are considered to be the high-risk treatments for $\mathrm{OBI} /$ resolved patients in addition to HBV carrier patients. Thus, these treatments should commence with special attention and continuous monitoring of the viral status. Anti-CD20 agents are the most reported ones that are categorized in this group. In these treatments, B cells, which are the main players in suppressing viral replication, will be targeted. Thus, considering the stability of cccDNA in the nucleus, a rapid decrease in B lymphocytes (B cells) population, even in the absence of HBV replication, leads to the reactivation of viral activity. In contrast, some other agents are considered as risk factors only in positive HBsAg patients, but not a serious menace in occult or resolved patients. For example, $\mathrm{HBVr}$ is rare in non-HBsAg carriers, due to the use of methotrexate (MTX) or azathioprine (AZA). There is evidence that these treatments manipulate cellular responses more than humoral responses. The suppression of $\mathrm{T}$ cell immunity can cause $\mathrm{HBVr}$ in HBsAg carriers with low HBV replication. In treatments with MTX and AZA, the levels of different cytokines were significantly decreased, including interferon- $\gamma$ (IFN$\gamma$ ) and tumor necrosis factor-alpha (TNF- $\alpha$ ), which are responsible for the suppression of viral replication.

In order to overcome or at least decrease, the risk of the global menace of HBVr, there are two available options in addition to identifying the patients in a high-risk condition and in continuous monitoring. The first option, which is not practical most of the time and may be followed by irreparable consequences, is the reduction or discontinuation of the responsible therapy. The second option, and the most common, is the initiation of prophylactic therapy before or at the same time of starting immunosuppressant medications. Almost all studies have confirmed the effectiveness of this approach. Despite this consensus, the timing of initiation and optimal duration of antiviral therapy has remained controversial, especially after rituximab administration or hematopoietic stem cell transplant (HSCT) (4). The risk of drug resistance is another critical factor, which has been warned of by various bodies (5-7). In this review, the latest findings associated with the risk of $\mathrm{HBVr}$, due to several treatment strategies, were evaluated. Different approaches for the management and prevention of HBV-infected patients in multiple conditions were also discussed.

\section{Immune System Response and Hepatitis B Virus In- fection}

Host immune response plays a critical role in HBVrelated hepatocyte damage. Strong cellular and humoral immune responses are associated with resolution and long-life antiviral responses in HBV infection (8). However, weakening of the cellular immune responses could cause an increase in HBV replication that leads to HBVr. Immunosuppressive therapy establishes the weak and narrowly focused immune responses due to a decrease in proliferation of the involved immune cells in inhibition viral replication, including B cells, T cells, and NK cells. It is followed by an increase in HBV replication and then HBVr. In addition to this indirect mechanism on $\mathrm{HBVr}$ induction, it was found that glucocorticoid stimulates hepatitis B viral gene expression, which finally results in an increase in viral replication (9). It is considered to be the direct effect of this type of immunosuppressive therapy.

In HBV infection, multiple cells and cytokines are involved. T cells and B cells are responsible for adaptive immunity, which plays the central role in control and clearing pathogens. NK cells are considered to be the other involved cells during infections. These cells are defined as the effector lymphocytes of an innate immunity endowed with constitutive cytolytic functions (10).

CD4+ T cells play an important role in HBV infection by the secretion of $\mathrm{T}$ helper 1 associated cytokines, such as IFN- $\gamma$ and TNF- $\alpha$, which down-regulate HBV replication. These are major antiviral cytokines that inhibit HBV replication and promote HBV clearance (11). In some autoimmune diseases, such as rheumatoid arthritis (RA), in which TNF- $\alpha$ is known as the major cause of damage, inhibition of this cytokine with some anti-TNF- $\alpha$ agents, including infliximab, etanercept, and adalimumab, is frequently used (12). It was found that inhibition of this proinflammatory cytokine leads to an increase in viral replication $(13,14)$. In 
fact, there is a deep relation between TNF- $\alpha$ and viral status in HBV infection. Several studies that found a correlation between the TNF- $\alpha$ gene polymorphism, HBV clearance, and CHB support this idea (15-17).

CD4+ T cells also act as the CD8+ T cells' promoters as well as inducers of B cells' activation and differentiation, which results in vigorous immune responses. CD8+ T cells destroy infected hepatocytes in addition to their non-lysis manner. HBV-specific CD8+ T cells inhibit HBV production through the production of some cytokines, such as IFN- $\gamma$ and TNF- $\alpha$, which are able to suppress HBV gene expression and replication without destroying the infected cells. Phillips et al. (18) revealed that CD8+ T cells inhibit HBV replication in HBV-producing hepatocytes with minimal cell lysis. In fact, inhibition of viral replication is mediated predominantly by non-cytolytic mechanisms via IFN- $\gamma$ and TNF- $\alpha$ contribution. In addition to T cells, B cells are deeply involved during HBV infection. These cells play the role in antigen presentation as well as viral clearance (19). It was found that the hepatitis B core antigen ( $\mathrm{HBcAg}$ ) can also cause the activation of naïve human $B$ cells in vivo in a Tcell-independent way (20). Recently, NK cells have been increasingly valued in their effects on HBV infection. In both the early immune responses and the chronic phase, these types of cells contribute to HBV infection. Wu et al. (21) reviewed the role of NK cells in HBV infection, discussing the mechanisms of action of this arm of the innate immune system in HBV infection.

The lack of, or exhaustion of, one of these cells and cytokines may result in the growth of viral replication and the development of HBVr in HBV inactive carriers, occult, and resolved HBV patients. The weakening or the absence of virus-specific T-cell reactivity is usually observed during human CHB infection (22). This situation causes poor effector cytotoxic activity and impaired cytokine production.

\section{Hepatitis B Virus Reactivation Definition}

In general, during immunosuppressive therapy, $\mathrm{HBVr}$ can occur after high HBV replication, which has no clinical sign. Indeed, HBVr starts with immune reconstitution, and has the same symptoms as acute hepatitis. Because HBVr is caused by immune reconstitution, and is not directly due to viral replication, patients will not benefit from the initiation of antiviral therapy during this phase. Recently author discussed about distinction between the HBVr and HBV flare and proper approaches to management of each condition (23).

In the literature, there are several definitions of $\mathrm{HBVr}$, which range from an asymptomatic rise in alanine transaminase (ALT) levels to severe hepatitis, which may result in serious liver injury, liver failure, and death (24).
In some studies, the elevation of ALT and HBV DNA levels $>2000 \mathrm{IU} / \mathrm{mL}$ in inactive HBsAg carriers or resolved hepatitis patients is considered to be a factor of reactivation $(7,25)$. Reverse seroconversion from the hepatitis $B$ virus e antibody (HBeAb) to the hepatitis $B$ virus e antigen (HBeAg) is also known as another sign of HBVr (26). HBsAg may change from negative to positive during HBVr, which is known as reverse seroclearance. This phenomenon has been considered as HBVr in the literature $(27,28)$. This could happen in the presence or the absence of HBsAb. Based on the literature, a 10-fold increase in HBV DNA levels ( $1-\log$ ) or more from the baseline level in serum can be considered as evidence of $\operatorname{HBVr}(24,29)$. It is essential to know the similar conditions to $\mathrm{HBVr}$, which are not considered as reactivation. Acute $\mathrm{HBV}$, the immune clearance phase in patients with $\mathrm{CHB}$, drug resistance, co-infection, and hepatotoxins can cause the development of signs, which are the same as HBVr and may be confused with reactivation.

\section{Conditions With the Risk of Hepatitis B Virus Reacti- vation}

$\mathrm{HBVr}$ is not limited to positive HBsAg patients. It also may develop during or after immunosuppressive therapy in patients with a positive antibody to the hepatitis B core antibody (anti-HBc) (30-32). Various studies reported clinical and virological reactivation in patients with $\mathrm{OBI}(30,31)$. Furthermore, reports revealed that HBVr may also occur in resolved patients after immunosuppression $(32,33)$.

All of the discussed reactivation forms were in a situation of past or current infections. However, Feeney et al. (34) reported a case that questions the dependability of anti-HBc testing before immunosuppressant therapy. It was claimed that pre-screening serology indicated negative HBsAg and anti-HBc. However, the patient developed a weak HBsAg with a low HBV DNA level $(<1000 \mathrm{IU} / \mathrm{mL})$ followed by rituximab-based treatment. HBV DNA reached a peak at $1 \times 10^{6} \mathrm{IU} / \mathrm{mL}$ after 5 months, which was treated with tenofovir (TNV). Interestingly, the patient remained negative anti-HBc.

Generally, each agent that causes a weakening of immune responses may lead to HBVr. HBsAg carriers, patients with $\mathrm{OBI} /$ resolved $\mathrm{HBV}$ infection who receive chemotherapy, those treated for autoimmune diseases, or those undergoing transplantation, are at risk of HBVr.

\subsection{Chemotherapy}

$\mathrm{HBVr}$ is a common problem in patients with $\mathrm{CHB}$ or even recovered patients who are under chemotherapy. Several chemotherapeutic agents are associated with HBVr, including anthracyclines, glucocorticoids, and anti-CD20 
agents. The rate of reported HBVr during or after the cessation of cancer chemotherapy varies widely and strongly depends on the underlying disease and the treatment regimens. For example, the incidence of HBVr in patients with breast cancer who were under chemotherapy without prophylaxis, was reported to range from $20 \%$ to $41 \%$ (2, 35-37). However, these rates dramatically decreased via the employment of prophylaxis. Recently, Yang et al. (38) analyzed gastric or colorectal cancer patients with positive HBsAg undergoing chemotherapy. The rate of reactivation was reported to be $14.6 \%$ ( 6 from 35 ). In a review, the rates of $\mathrm{HBVr}$ in chronic carriers with hepatocellular carcinoma (HCC) undergoing chemotherapy were reported to range from $4 \%$ to $67 \%$ (39). Furthermore, there are several case reports of $\mathrm{HBVr}$ in patients with chronic myeloid leukemia under chemotherapy $(40,41)$.

\subsection{Treating Autoimmune Diseases}

The most effective therapy in several autoimmune diseases is corticosteroids, which are widely used in the treatment of these diseases and are associated with HBVr. It has been shown that increasing the dose of corticosteroids can raise the risk of infections (42). The risk of HBVr could significantly increase in patients who received prednisone at high doses ( $\geq 20 \mathrm{mg} /$ day for at least 4 weeks). In addition to corticosteroids, TNF- $\alpha$ inhibitors also led to the appearance of reactivation signs (43-47). In TNF- $\alpha$ targeted therapy, 39\% and 5\% reactivation in HBsAg carriers and positive anti-HBc patients, respectively, were reported (47).

The newly emerged therapy, rituximab, which targets B cells, is widely used in chemotherapy as well as in various autoimmune disease therapies. This treatment is considered to be a most serious risk factor of HBVr in autoimmune diseases. Several studies have reported the reactivation of HBV due to rituximab administration in RA patients $(33,48,49)$. In contrast to many other immunosuppressants, HBVr due to rituximab administration may happen after 6 months (up to 12 months). This may be explained by the delay in immune reconstitution in these cases. Thus, in addition to immediate initiation of antiviral therapy, prophylactic antiviral therapy for at least 12 months was recommended after rituximab administration, in various studies $(5,6)$.

\subsection{Transplantation}

Although HBVr is defined as the reappearance of HBV, the appearance of HBV after transplantation also has been mentioned as the HBVr in many studies. Various studies confirmed the chance of HBV appearing during solid organ transplantation, bone marrow transplantation, or HSCT (4, 33, 50-57). Blanpain et al. (58) reported three cases of HBV appearing after transplantation in patients with resolved $\mathrm{HBV}$ infection (negative $\mathrm{HBsAg}$, positive $\mathrm{HB}$ $\mathrm{sAb}$, and anti-HBc). It is considered to be a serious warning for the awareness of HBVr risk during transplantation in resolved HBV patients. Furthermore, Mikulska et al. (56) reported HBVr within a median of 19 months after HSCT, ranging from 9 months to 77 months. This could be a warning that HBVr can occur even some years after HSCT. In order to prevent $\mathrm{HBVr}$ in transplantation, the American society of transplantation and the American society of blood and marrow transplantation released guidelines associated with the reactivation of HBV after transplantation $(59,60)$.

In patients receiving allogeneic HSCT, HBVr occurs more frequently than in those who receive autologous HSCT. This may be explained by the reduced suppression of innate cellular immunity in autologous HSCT $(3,54)$. However, reverse seroclearance of $\mathrm{HBV}$ is not rare in autologous HSCT (53). The effect of antiviral therapy in cases with HSCT, regardless of donor type, has been confirmed by several authors $(4,54,61)$. However, recently, it was found that short-term antiviral prophylaxis appeared insufficient to decrease the risk of HBVr. Prophylaxis longer than 24 months was introduced as a more effective way of controlling viral replication for patients under HSCT (54).

\section{Risk Factors}

Most people who experienced recovery from HBV infection had an undetectable HBV DNA serum (62). People with this condition are still in danger of $\mathrm{HBVr}$, but the risk is less than in those with positive HBsAg and those with detectable HBV DNA serum. This can be explained with the persistence of $\mathrm{HBV}$ in the liver. The reactivation frequency can change among less than $1 \%$ and more than $50 \%$ which mainly depends on different risk factors.

\subsection{Viral Status}

Viral status is another important factor associated with the risk of HBVr. According to many reports, viral replication in patients with positive HBsAg is higher than in those with negative $\mathrm{HBsAg}$, positive anti-HBc. Indeed, positive HBsAg is considered to be a risk factor of $\operatorname{HBVr}(63,64)$. Furthermore, HBV DNA serum levels can lead to a significantly higher risk of $\mathrm{HBVr}$ compared to the patients with a low or undetectable level of HBV DNA.

Different studies have suggested that low titer or the absence of HBsAb is strongly associated with $\operatorname{HBVr}(54,65$ 68). However, recently, a meta-analysis containing 578 patients in 15 different studies did not find HBsAb status to be effective on reactivation risk (69). 
It was suggested that in patients with HBeAg-positive, HBVr more likely could be developed than in those with HBeAg-negative (70-71). Recently, in HCC patients who experienced HBVr, a significant correlation between HBeAg status in those with low serum HBV DNA level was found (71). HBV DNA may be considered as the most important factor associated with $\operatorname{HBVr}(65,72)$. In addition to these factors, non-A HBV genotypes are known as the other viral factors associated with a higher risk of reactivation (73).

\subsection{Host Factors}

Being male, especially a younger male, is considered to be a risk factor for HBV in several studies $(70,74)$. In a study that introduced this point, 18 patients were found to be HBsAg-positive among 626 patients undergoing cytotoxic chemotherapy. In 15 patients, reactivation was observed: 11 (73\%) were male and 4 (27\%) were female, which is a significant difference. In HBsAg carriers who did not experience reactivation, there were 27 (43\%) male and 36 (57\%) female. In that study, a strong relation between the male sex and the risk of HBVr in HBsAg-positive patients was found (70). In another study, which reported $\mathrm{HBV}$ in an inactive phase of CHB in Alaska, the male sex was dominant in reactivated cases (22 of 179 patients (12\%) in the male group and 14 of 235 patients (6\%) in the female group) (75). There was no clear association between age and HBVr in that study. Additionally, HBVr developed earlier in the male group.

\subsection{Underlying Disease and Therapy Regimens}

Based on previous reports, the most common underlying disease associated with $\mathrm{HBVr}$ is lymphoma, which is followed by breast cancer $(66,70,72)$. This may be the result of marked immunosuppression in lymphoma patients and anthracycline-based chemotherapeutic in patients with breast cancer. It also may be due to the high prevalence of HBV infection among those patients (76). The incidence of $\mathrm{HBVr}$ in patients with lymphoma is reported to range from $20 \%$ to $73 \%$, which could be explained by the frequent use of the anti-CD20 agent (rituximab) to treat this disease $(24,29,77-79)$. Furthermore, this risk is high in patients with breast cancer. It has been reported to range from $20 \%$ to $41 \%$, which is a significantly high risk $(2,35-37)$. Although there are various reports of $\mathrm{HBVr}$ in patients with rheumatic diseases $(33,43,48)$, the rate of reactivation is not as high as the previously mentioned diseases. In a study including $122 \mathrm{HBsAg-positive} \mathrm{patients} \mathrm{with}$ rheumatic diseases who were under treatment of anti-TNF$\alpha$ agents or disease modifying anti-rheumatic drugs, 15 cases (12.3\%) developed $\mathrm{HBVr}$ (80). However, in another report, anti-TNF- $\alpha$ therapy was considered to be a safe option for the treatment of rheumatic diseases in patients with
CHB infection when it was combined with antiviral therapy. Also, it was concluded that anti-TNF- $\alpha$ therapy could be safe in resolved HBV patients with rheumatic diseases without using HBV prophylaxis (81).

The risk of HBVr in patients with HCC who are undergoing chemotherapy is very high. It can be explained by the high number of HBV carriers among HCC patients. Various studies have found that approximately $80 \%$ of HCC patients in high HBV endemic regions are HBsAg-positive. Furthermore, more than $90 \%$ of HCC cases are anti-HBcpositive. Interestingly, population controls typically had rates of HBsAg between $10 \%$ and $15 \%$ (82). Because HCC is caused by several HBV-related mechanisms, the prevalence of HBV is significantly higher in HCC patients compared to controls. Considering the high number of HBV carriers among HCC patients, immunosuppressive therapy leads to an increase in viral replication in these patients. Following that, during immune reconstitution, the signs of HBVr will appear. Various studies reported HBVr in patients with HCC who received chemotherapy (39, 71, 74). The incidence of HBVr in patients with HCC varied widely in range with significant mortality. Yeo et al. (74) reported a high rate of mortality (30\%) between 37 reactivated conditions of 102 HBsAg-carrier patients with HCC under systemic chemotherapy. It seems that the high rate of $\mathrm{HBVr}$ among those with HCC is the outcome of increased viral replication, but this is not comparable to $\mathrm{HBV}$ reactivation from a state of inactive infection or OBI.

Generally, various treatments, including corticosteroids, anti-CD20 agents, HSCT, TNF- $\alpha$ inhibitors, anthracyclines, transarterial chemoembolization for HCC, methotrexate, ustekinumab, and tyrosine kinase inhibitors, can cause increasing risk of HBVr. Table 1 indicates the HBVr risk of some selected treatments in HBsAg carriers and non-HBsAg carriers.

Rituximab and ofatumumab are the two major B cell inhibitors (anti-CD20), which were identified as very highrisk treatments in HBV-infected patients (risk of reactivation $>20 \%$ ). Rituximab is a chimeric anti-human CD20 antibody, which was approved by the U.S. Food and Drug Administration (FDA) in 1997 for non-Hodgkin lymphoma treatment. Then its usage was extended to multiple diseases as approved and to off-label groups. It acts directly against the CD20 antigen expression on the surface of $\mathrm{B}$ cells. It is becoming recognized that rituximab is strongly associated with an increase in the risk of $\operatorname{HBVr}(28,33,48$, 49, 67-69, 83). The first HBVr-associated study on rituximab therapy was published in 2001, which described a patient who had HBsAb, but not HBsAg before rituximab therapy (84). A meta-analysis was investigated on HBVr in patients with lymphoproliferative diseases who were receiving rituximab from emersion of rituximab through 2009 
Table 1. The Risk of Hepatitis B Virus Reactivation Due to Some Selected Treatments in Hepatitis B Surface Antigen Carriers and Non-Hepatitis B Surface Antigen Carriers

\begin{tabular}{lll}
\hline Risk & HBsAg+ & HBsAg-, anti-HBc+ \\
\hline Very high (> 20\%) & Rituximab; ofatumumab; hematopoietic stem cell transplantation & NA \\
\hline High (10-20\%) & $\begin{array}{l}\text { Doxorubicin; epirubicin; high dose of prednisone ( }>20 \mathrm{mg},>4 \\
\text { weeks); Anti-CD52 (alemtuzumab) }\end{array}$ & Rituximab; ofatumumab \\
\hline Moderate (1-10\%) & $\begin{array}{l}\text { Infliximab; etanercept; adalimumab; ustekinumab; natalizumab; } \\
\text { vedolizumab; imantinib; nilotinib; combination cytotoxic } \\
\text { chemotherapy (without corticosteroids); anti-rejection therapy for } \\
\text { solid organ transplant recipients; moderate prednisone therapy ( }>20 \\
\text { mg, }<4 \text { weeks) }\end{array}$ & $\begin{array}{l}\text { Infliximab; etanercept; adalimumab; ustekinumab; natalizumab; } \\
\text { vedolizumab; imantinib; nilotinib }\end{array}$ \\
\hline Low $(<\mathbf{1} \%)$ & $\begin{array}{l}\text { Methotrexate; azathioprine; 6-mercaptopurine; mild prednisone } \\
\text { therapy (<20 mg, < 1 week) }\end{array}$ & NA \\
\hline Rare $(<\mathbf{1} \%)$ & NA & Methotrexate; azathioprine \\
\hline
\end{tabular}

(85). It revealed that the median number of rituximab doses received before HBVr was 6 (between 3 and 10). This analysis indicated the sooner reactivation after the last dose of rituximab in HBsAg-positive patients compared to HBsAg-negative and anti-HBc-positive patients (median of 1 month vs. 5 months).

Also, there is limited proof regarding the safety of rituximab therapy in RA patients with CHB (86). van Vollenhoven et al. (87) reported no HBVr among 131 anti-HBcpositive patients with RA who received up to 16 courses of rituximab. Despite these studies, it seems that rituximab increases the risk of reactivation in RA patients. This phenomenon was confirmed by several other studies, which reported HBVr development after rituximab therapy between RA patients $(33,48,83)$.

Similar to rituximab, ofatumumab is classified as an anti-CD20 drug. It was approved in 2009 and is used for the treatment of chronic lymphocytic leukemia in patients who have the future disease after anti-cancer therapy. Since this is a relatively new drug, the excessive ability of ofatumumab to cause HBVr was not confirmed, although it seems that it can lead to reactivation of HBV as rituximab does. The FDA warned about the risk of HBVr for patients who were administered ofatumumab. In this issue, the FDA recommended the screening of all patients for hepatitis B prior to receiving ofatumumab (88).

All the TNF- $\alpha$ inhibitors, including infliximab, adalimumab, certolizumab, golimumab, and etanercept, may cause HBVr in HBsAg carriers in addition to patients with $\mathrm{OBI} /$ resolved HBV infection. Anti-TNF- $\alpha$ therapy can be considered as a lower risk factor compared to rituximab or most of the chemotherapy regimens. There are various studies that reported no HBVr in patients during anti-TNF$\alpha$ therapy $(89,90)$. However, in some reports, HBVr was observed in cases under anti-TNF- $\alpha$ therapy $(44,91)$. The first report of HBVr due to TNF- $\alpha$ inhibitors was published in 2003 (92). After that article, HBVr due to anti-TNF- $\alpha$ ther- apy was reported by several other authors (43, 47, 91). After identifying the capability of infliximab to inducing $\mathrm{HBVr}$ the FDA inserted a warning regarding $\mathrm{HBVr}$ for the use of infliximab.

\section{Management of Patients With a Risk of Hepatitis B Virus Reactivation During Immunosuppressive Ther- apy or Chemotherapy}

Considering that most of the HBV-infected patients are not aware of their infection, it is essential to screen all the candidate patients prior to immunosuppressive therapy or chemotherapy. The urgency of screening may change in various areas with a different prevalence of HBV infection. In HBV-endemic regions, the implementation of HBsAg and anti-HBc is more urgent than regions with a lower prevalence of HBV infection. The screening of anti$\mathrm{HBc}$ may be as important as the screening of HBsAg prior to immunosuppressive therapy or chemotherapy. Guidelines from the international liver society recommended mandatory screening for serum HBsAg and anti-HBc before starting all forms of immunosuppression $(7,25)$. Depending on the potency of the drugs, the underlying disease, and the viral factors, the risk of HBVr in those under immunosuppressant therapies can be significantly reduced by HBV antiviral prophylaxis. Receiving HBV antiviral agents at the commencement of immunosuppressive therapy or chemotherapy was demonstrated to be effective in decreasing the risk of HBVr. Prophylaxis also could be initiated before starting therapy. For the most immune suppressive regimes, prophylaxis should continue for at least 6 months after cessation of immunosuppressive drugs. Additionally, it has been recommended that antiviral prophylaxis must continue after 12 months after cessation of rituximab therapy (85). Relatively early withdrawal of prophylactic treatment must be strongly 
avoided in cases under HSCT, even in the presence of complete remission $(52,61)$. Thus, prophylaxis longer than 24 months was recommended for these patients (54). On the issue of HSCT, several studies have reported HBVr after more than 12 months, reaching a peak of 91 months $(27,54$, $56,61)$.

Considering the high resistance to lamivudine (LAM), in addition to various reported cases with a risk of reactivation following more than 6 months from the cessation of immunosuppressive therapy or chemotherapy, it is recommended that referenced HBV antiviral agents, such as entecavir (ETV) and TNV should be used in therapies that need long-term prophylaxis. Recommendations of various bodies associated with HBVr are shown in Table 2.

In a meta-analysis, LAM prophylaxis in HBsAg carriers with breast cancer under chemotherapy was introduced as an effective option in the reduction of $\mathrm{HBVr}$ (95). Based on a systematic review, LAM prophylaxis had appeared as an effective option in the reduction of HBVr in HBsAg-positive lymphoma patients undergoing chemotherapy. After that, preventing reactivation caused a decrease in the disruption of the chemotherapy (96).

In another report, anti-HBc-positive patients under immunosuppressive therapy were included (97). These patients suffered from various autoimmune diseases. Among those who had received antiviral therapy, none indicated a rise in HBV DNA levels, while $11.5 \%$ of the control group did experience an increase. ALT elevation was significantly lower in the antiviral prophylactic group. Additionally, one patient in the control group showed reverse seroconversion. In contrast, no reverse seroconversion was observed in the prophylactic group.

LAM can be considered as the most common prophylaxis in $\mathrm{HBV}$ patients. However, there is a considerable risk of LAM resistance risk in patients with active HBV. Based on the literature, LAM is an appropriate choice in cases with high viral replication that need short-term treatments. In contrast, it was not recommended for HBsAg carriers with detectable HBV DNA levels at baseline, who are candidates for long-term immunosuppressive therapy. Accordingly, it can be concluded that LAM prophylaxis is a reasonable choice for OBI/resolved HBV patients.

LAM is more common in countries with a high prevalence of $\mathrm{HBV}$, where the cost of other antivirals may be prohibitive. Considering the high resistance rate of LAM, it is recommended that it be used for short-term treatment. By LAM resistance, the cessation of immunosuppressive therapy or chemotherapy may be necessary in order to control viral replication. ETV is known as the other antiviral prophylaxis with a lower chance of resistance compared to LAM. ETV was also introduced as a more effective antiviral therapy in preventing HBVr in several studies (98,
99). In a study including 121 patients with on treated diffuse large B cell lymphoma receiving R-chop chemotherapy, the rate of $\mathrm{HBVr}$ was reported at $13.3 \%$ in cases that used LAM in a dose of $100 \mathrm{mg}$ daily. In contrast, no reactivation was observed in the ETV users group with $0.5 \mathrm{mg}$ daily (99). It was recommended that ETV be used in preference to LAM in CHB patients who have detectable HBV DNA levels at baseline (98). There is a positive correlation between the chance of LAM resistance and ETV resistance. Lee et al. (100) conducted a retrospective cohort study to evaluate the probability of developing genotypic resistance to ETV in LAM-exposed patients. They found that patients with previous exposure to LAM developed ETV resistance significantly more frequently than nucleos(t)ide analogue (NA)naive patients. The probabilities of developing ETV resistance in the NA-naïve, LAM peri-exposure group without resistance and with resistance were $<1.0 \%, 8.0 \%$, and $28.2 \%$, respectively, at month 48 . This study revealed the high risk of ETV therapy in patients with prior exposure to LAM, regardless of the presence or absence of LAM resistance. Adefovir and LAM combination therapy was reported as an effective suppression viral replication in patients with LAM resistance (101). Since, TNV was licensed for HBV therapy, it is increasingly being used because of its high efficiency and low rate of resistance. It was reported as the effective alternative for the treatment of patients with LAM resistance (102). Furthermore, TNV was identified as being highly effective and safe in the prophylaxis and rescue treatment of HBVr in patients under immunosuppression therapy (103). Figure 1 indicates our recommendation, based on different studies and reported cases associated with $\mathrm{HBVr}$ and using antiviral prophylactic therapy in order to control the disease. 
Table 2. The Most Important Recommendations of Various Bodies Associated With Hepatitis B Virus Reactivation

\begin{tabular}{|c|c|c|c|c|}
\hline Recommending Body & Recommended Tests & Pre-Emptive/Prophylaxis & Duration & Recommendation \\
\hline $\begin{array}{l}\text { American association for the study of } \\
\text { liver diseases (2009) (25) }\end{array}$ & HBsAg; anti-HBC & LAM; ETV; TNV; TLV & $\begin{array}{l}\text { If the baseline of } \mathrm{HBV} \text { DNA }<2000 \mathrm{IU} / \mathrm{mL} \text {, } \\
\text { it should be kept } 6 \text { months after the end } \\
\text { of immunosuppressive therapy or } \\
\text { chemotherapy. If the baseline of HBV DNA } \\
>2000 \mathrm{IU} / \mathrm{mL} \text {, antiviral therapy should be } \\
\text { kept until it reaches the treatment } \\
\text { endpoint }\end{array}$ & $\begin{array}{l}\text { LAM or TLV can be used in short-term } \\
\text { treatment }(<12 \text { months) and } \\
\text { non-detectable HBV DNA, TNV, or ETV are } \\
\text { useful in long-term treatment periods. } \\
\text { IFN- } \gamma \text { should be avoided in view of the } \\
\text { bone marrow suppressive effect }\end{array}$ \\
\hline 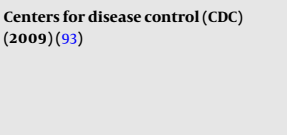 & HBsAg; anti-HBc; HBsAb & Not specified & $\begin{array}{l}\text { Optimal duration of therapy has not been } \\
\text { established }\end{array}$ & $\begin{array}{l}\text { Anti-HBc-positive patients should be } \\
\text { monitored closely for signs of liver } \\
\text { disease. HBsAg-positive patients should } \\
\text { be treated before starting } \\
\text { immunosuppressive therapy or } \\
\text { chemotherapy }\end{array}$ \\
\hline $\begin{array}{l}\text { European association for the study of } \\
\text { the liver (EASL) (2012) (7) }\end{array}$ & HBsAg; anti-HBc & $\begin{array}{l}\text { LAM; ETV; TNV. LAM can reduce the risk of } \\
\text { HBVr, but it is better to use a high barrier } \\
\text { to resistance drugs, such as ETV and TNV }\end{array}$ & $\begin{array}{l}12 \text { months after cessation of } \\
\text { immunosuppressive therapy or } \\
\text { chemotherapy, regardless of HBV DNA } \\
\text { levels }\end{array}$ & $\begin{array}{l}\text { In HBSAg-positive patients and those with } \\
\text { negative HBSAg, anti-HBc-positive } \\
\text { patients with detectable HBV DNA levels, } \\
\text { antiviral therapy should be started as } \\
\text { soon as possible. However, in patients } \\
\text { with negative HBsAg, anti-HBc-positive } \\
\text { patients with detectable HBV DNA levels, } \\
\text { careful follow-up is enough. With the } \\
\text { appearance of HBVr signs, antiviral } \\
\text { therapy should be started. Vaccination of } \\
\text { HBV seronegative patients is highly } \\
\text { recommended before } \\
\text { immunosuppressive therapy or } \\
\text { chemotherapy }\end{array}$ \\
\hline $\begin{array}{l}\text { Asian pacific association for the study } \\
\text { of the liver (APASL) (2012)(94) }\end{array}$ & $\begin{array}{l}\text { HBsAg; anti-HBc (in treatment with } \\
\text { biological agents) }\end{array}$ & LAM; ETV; TNV & $\begin{array}{l}\text { Start before commencement of therapy } \\
\text { and up to at least } 6 \text { months after the end } \\
\text { of immunosuppressive therapy } \\
\text { orchemotherapy }\end{array}$ & $\begin{array}{l}\text { In anti-HBC negative, anti-HBc positive } \\
\text { patients, HBV DNA should be closely } \\
\text { monitored. If it was needed, treatment } \\
\text { should be started. }\end{array}$ \\
\hline $\begin{array}{l}\text { American society of clinical oncology } \\
\text { (2015)(6) }\end{array}$ & HBsAg; anti-HBC & $\begin{array}{l}\text { Drugs with low rates of viral resistance, } \\
\text { such as ETV and TNV. LAM was not } \\
\text { recommended in long durations of } \\
\text { systemic cancer therapies }\end{array}$ & $\begin{array}{l}\text { Patients with CHB or clinically resolved } \\
\text { HBV infection should receive durations of } \\
\text { prophylactic antiviral therapy beyond } 12 \\
\text { months }\end{array}$ & $\begin{array}{l}\text { For HBsAg carriers, antiviral therapy } \\
\text { should be initiated and continued for } \\
\text { approximately } 6 \text { - } 12 \text { months after } \\
\text { completing cancer therapy. In HBSAg } \\
\text { negative, anti-HBc-positive patients, HBV } \\
\text { DNA and ALT testing should be done } \\
\text { approximately every } 3 \text { months during } \\
\text { therapy and antiviral therapy should be } \\
\text { started promptly if HBVr occurs }\end{array}$ \\
\hline $\begin{array}{l}\text { American gastroenterological } \\
\text { association institute (AGA) (2015) (5) }\end{array}$ & $\begin{array}{l}\text { HBsAg; anti-HBc; HBV DNA test (if HBsAg is } \\
\text { positive) }\end{array}$ & $\begin{array}{l}\text { Antiviral drugs with a high barrier to } \\
\text { resistance over LAM }\end{array}$ & $\begin{array}{l}\text { Continue for at least } 6 \text { months after } \\
\text { discontinuation of immunosuppressive } \\
\text { therapy. It must be increased to at least } 12 \\
\text { months for B-cell-depleting agents. }\end{array}$ & $\begin{array}{l}\text { Antiviral prophylaxis was suggested for } \\
\text { all risk groups. Antiviral drugs with a } \\
\text { high barrier to resistance over LAM for } \\
\text { prophylaxis in patients undergoing } \\
\text { immunosuppressive drug therapy was } \\
\text { not a strong recommendation. However, } \\
\text { using these types of antiviral agents for } \\
\text { established HBVr in patients undergoing } \\
\text { immunosuppressive drug was strongly } \\
\text { recommended. }\end{array}$ \\
\hline
\end{tabular}

Abbreviations: Anti-HBc, antibody to hepatitis B core antigen; ETV, entecavir; HBV, hepatitis B virus; HBsAb, hepatitis B surface antibody; HBsAg, hepatitis B surface antigen; HBVr, hepatitis B virus reactivation; IFN- $\gamma$, interferon- $\gamma$; LAM, lamivudine; TLV, telbivudine; TNV, tenofovir. 


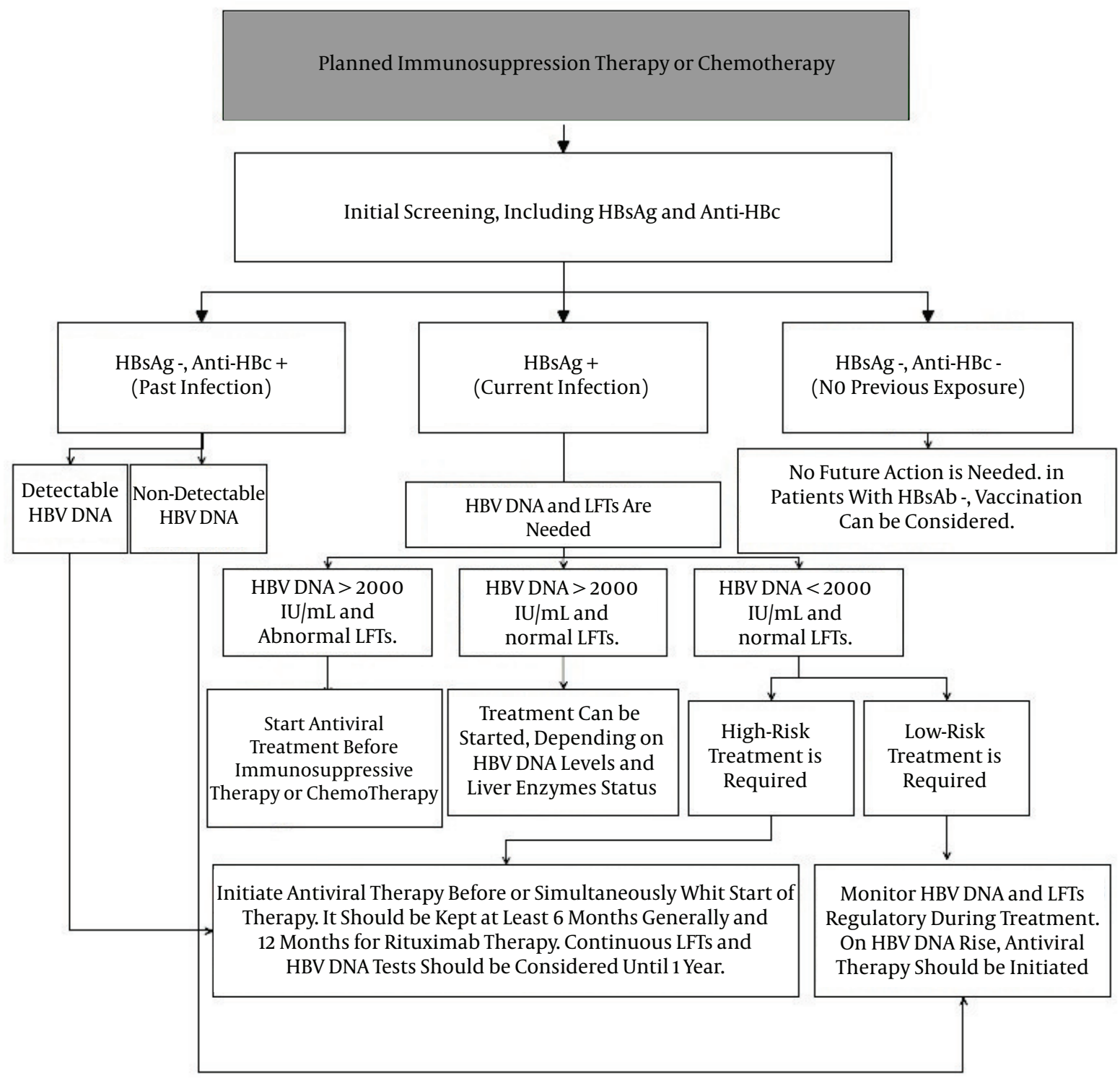

Anti-HB, antibody to hepatitis B core antigen; HBV, hepatitis B virus; HBsAg, hepatitis B surface antigen; LFTs, liver function tests. 


\section{References}

1. World Health Organisation. . Hepatitis B [cited 3 October 2015]. Available from: http://www.who.int/csr/disease/hepatitis/ whocdscsrlyo20022/en/index1.html.

2. Yeo W, Chan PK, Hui P, Ho WM, Lam KC, Kwan WH, et al. Hepatitis $B$ virus reactivation in breast cancer patients receiving cytotoxic chemotherapy: a prospective study. J Med Virol. 2003;70(4):553-61. doi: 10.1002/jmv.10430. [PubMed: 12794717].

3. Moses SE, Lim Z, Zuckerman MA. Hepatitis B virus infection: pathogenesis, reactivation and management in hematopoietic stem cell transplant recipients. Expert Rev Anti Infect Ther. 2011;9(10):891-9. doi: 10.1586/eri.11.105. [PubMed: 21973301].

4. Liao YP, Jiang JL, Zou WY, Xu DR, Li J. Prophylactic antiviral therapy in allogeneic hematopoietic stem cell transplantation in hepatitis B virus patients. World J Gastroenterol. 2015;21(14):4284-92. doi: 10.3748/wjg.v21.i14.4284. [PubMed: 25892880].

5. Reddy KR, Beavers KL, Hammond SP, Lim JK, Falck-Ytter YT, American Gastroenterological Association I. American Gastroenterological Association Institute guideline on the prevention and treatment of hepatitis B virus reactivation during immunosuppressive drug therapy. Gastroenterology. 2015;148(1):215-9. doi: 10.1053/j.gastro.2014.10.039. [PubMed: 25447850] quiz e16-7.

6. Hwang JP, Artz AS, Somerfield MR. Hepatitis B Virus Screening for Patients With Cancer Before Therapy: American Society of Clinical Oncology Provisional Clinical Opinion Update. J Oncol Pract. 2015;11(4):e487-9. doi: 10.1200/JOP.2015.004846. [PubMed: 25991637].

7. European Association For The Study Of The L. EASL clinical practice guidelines: Management of chronic hepatitis B virus infection. J Hepatol. 2012;57(1):167-85. doi: 10.1016/j.jhep.2012.02.010. [PubMed: 22436845].

8. Said ZN, Abdelwahab KS. Induced immunity against hepatitis B virus. World J Hepatol. 2015;7(12):1660-70. doi: 10.4254/wjh.v7.i12.1660. [PubMed: 26140085].

9. Chou CK, Wang LH, Lin HM, Chi CW. Glucocorticoid stimulates hepatitis B viral gene expression in cultured human hepatoma cells. Hepatology. 1992;16(1):13-8. [PubMed: 1319949].

10. Vivier E, Raulet DH, Moretta A, Caligiuri MA, Zitvogel L, Lanier LL, et al. Innate or adaptive immunity? The example of natural killer cells. Science. 2011;331(6013):44-9. doi: 10.1126/science.1198687. [PubMed: 21212348].

11. Carroll MB, Forgione MA. Use of tumor necrosis factor alpha inhibitors in hepatitis B surface antigen-positive patients: a literature review and potential mechanisms of action. Clin Rheumatol. 2010;29(9):1021-9. doi: 10.1007/s10067-010-1523-2. [PubMed: 20556450].

12. Mewar D, Wilson AG. Treatment of rheumatoid arthritis with tumour necrosis factor inhibitors. Br J Pharmacol. 2011;162(4):785-91. doi: 10.1111/j.1476-5381.2010.01099.x. [PubMed: 21039421].

13. Herbein G, O'Brien WA. Tumor necrosis factor (TNF)-alpha and TNF receptors in viral pathogenesis. Proc Soc Exp Biol Med. 2000;223(3):241-57. [PubMed: 10719836].

14. Kasahara S, Ando K, Saito K, Sekikawa K, Ito H, Ishikawa T, et al. Lack of tumor necrosis factor alpha induces impaired proliferation of hepatitis B virus-specific cytotoxic T lymphocytes. J Virol. 2003;77(4):2469-76. [PubMed: 12551985].

15. Xu J, Zhang S, Zhang Z, Fu L, Zheng Q, Wang J, et al. TNFalpha promoter region polymorphisms affect HBV virus clearance in southern Chinese. Clin Chim Acta. 2013;425:90-2. doi: 10.1016/j.cca.2013.07.015. [PubMed: 23895869].

16. Kao PC, Wu JF, Ni YH, Lin YT, Chen HL, Hsu SH, et al. Tumour necrosis factor-alpha promoter region polymorphisms affect the course of spontaneous HBsAg clearance. Liver Int. 2010;30(10):1448-53. doi: 10.1111/j.1478-3231.2010.02340.x. [PubMed: 20825556].
17. Zhang TC, Zhao YQ, Hu GL, Liu XQ, Huang XK. The relationship between tumour necrosis factor-alpha gene polymorphism and susceptibility and clearance of the persistent hepatitis B virus infection in a Chinese population: a meta-analysis. Clin Microbiol Infect 2014;20(3):227-34. doi: 10.1111/1469-0691.12257. [PubMed: 23701172].

18. Phillips S, Chokshi S, Riva A, Evans A, Williams R, Naoumov NV. CD8(+) T cell control of hepatitis B virus replication: direct comparison between cytolytic and noncytolytic functions. J Immunol. 2010;184(1):287-95. doi: 10.4049/jimmunol.0902761. [PubMed:19949099].

19. Chang JJ, Lewin SR. Immunopathogenesis of hepatitis B virus infection. Immunol Cell Biol. 2007;85(1):16-23. doi: 10.1038/sj.icb.7100009. [PubMed: 17130898].

20. Cao T, Lazdina U, Desombere I, Vanlandschoot P, Milich DR, Sallberg $\mathrm{M}$, et al. Hepatitis $\mathrm{B}$ virus core antigen binds and activates naive human B cells in vivo: studies with a human PBL-NOD/SCID mouse model.J Virol. 2001;75(14):6359-66. doi:10.1128/JVI.75.14.63596366.2001. [PubMed: 11413302].

21. Wu SF, Wang WJ, Gao YQ. Natural killer cells in hepatitis B virus infection. Braz J Infect Dis. 2015;19(4):417-25. doi 10.1016/j.bjid.2015.05.006. [PubMed: 26119852].

22. Ye B, Liu X, Li X, Kong H, Tian L, Chen Y. T-cell exhaustion in chronic hepatitis B infection: current knowledge and clinical significance. Cell Death Dis. 2015;6:e1694. doi: 10.1038/cddis.2015.42. [PubMed: 25789969].

23. Tavakolpour S. The new insight into management of hepatitis $B$ virus patients with flare. Immunology letters. 2016:173-77.

24. Lok AS, Liang RH, Chiu EK, Wong KL, Chan TK, Todd D. Reactivation of hepatitis $B$ virus replication in patients receiving cytotoxic therapy. Report of a prospective study. Gastroenterology. 1991;100(1):1828. [PubMed:1983820].

25. Lok AS, McMahon BJ. Chronic hepatitis B: update 2009. Hepatology 2009;50(3):661-2. doi: 10.1002/hep.23190. [PubMed: 19714720].

26. Shibolet O, Ilan Y, Gillis S, Hubert A, Shouval D, Safadi R. Lamivudine therapy for prevention of immunosuppressive-induced hepatitis B virus reactivation in hepatitis B surface antigen carriers. Blood. 2002;100(2):391-6. [PubMed: 12091327].

27. Lau GK, Leung YH, Fong DY, Au WY, Kwong YL, Lie A, et al. High hepatitis B virus (HBV) DNA viral load as the most important risk factor for $\mathrm{HBV}$ reactivation in patients positive for HBV surface antigen undergoing autologous hematopoietic cell transplantation. Blood. 2002;99(7):2324-30. [PubMed: 11895763].

28. Yeo W, Chan TC, Leung NW, Lam WY, Mo FK, Chu MT, et al. Hepatitis $\mathrm{B}$ virus reactivation in lymphoma patients with prior resolved hepatitis B undergoing anticancer therapy with or without rituximab. J Clin Oncol. 2009;27(4):605-11. doi: 10.1200/JCO.2008.18.0182. [PubMed: 19075267].

29. Lau GK, Yiu HH, Fong DY, Cheng HC, Au WY, Lai LS, et al. Early is superior to deferred preemptive lamivudine therapy for hepatitis B patients undergoing chemotherapy. Gastroenterology. 2003;125(6):1742-9. [PubMed: 14724827].

30. UyanikoGLu A, Sert U, Nar H, YenİCe N. Occult Hepatitis B Reac tivation After Chemoteraphy: A Case Report. Viral Hepatit Dergisi. 2015;21(2):56-8. doi: 10.4274/vhd.36025.

31. Du W, Zheng $Z$, Han $S$, Ma $S$, Chen $S$. HBV reactivation in an occult HBV infection patient treated with prednisone for nephrotic syndrome: case report and literature review. BMC Infect Dis. 2013;13:394. doi: 10.1186/1471-2334-13-394. [PubMed: 23977980].

32. Sera T, Hiasa Y, Michitaka K, Konishi I, Matsuura K, Tokumoto Y, et al. Anti-HBs-positive liver failure due to hepatitis $\mathrm{B}$ virus reactivation induced by rituximab. Intern Med. 2006;45(11):721-4. [PubMed: 16819252].

33. Ghrenassia E, Mekinian A, Rouaghe S, Ganne N, Fain O. Reac tivation of resolved hepatitis B during rituximab therapy for rheumatoid arthritis. Joint Bone Spine. 2012;79(1):100-1. doi: 10.1016/j.jbspin.2011.07.003. [PubMed: 21944979]. 
34. Feeney SA, McCaughey C, Watt AP, Agnaf MR, McDougall N, Wend UC, et al. Reactivation of occult hepatitis B virus infection following cytotoxic lymphoma therapy in an anti-HBc negative patient. J Med Virol. 2013;85(4):597-601. doi: 10.1002/jmv.23513. [PubMed: 23359331].

35. Lee HJ, Kim DY, Keam B, Lee JH, Han SW, Oh DY, et al. Lamivudine prophylaxis for hepatitis B virus carrier patients with breast cancer during adjuvant chemotherapy. Breast Cancer. 2014;21(4):387-93. doi: 10.1007/s12282-012-0417-3. [PubMed: 23073741].

36. Yun J, Kim KH, Kang ES, Gwak GY, Choi MS, Lee JE, et al. Prophylactic use of lamivudine for hepatitis B exacerbation in post-operative breast cancer patients receiving anthracycline-based adjuvant chemotherapy. BrJCancer. 2011;104(4):559-63. doi:10.1038/bjc.2011.4. [PubMed: 21285992].

37. Yeo W, Ho WM, Hui P, Chan PK, Lam KC, Lee JJ, et al. Use of lamivudine to prevent hepatitis B virus reactivation during chemotherapy in breast cancer patients. Breast Cancer Res Treat. 2004;88(3):209-15. doi: 10.1007/s10549-004-0725-1. [PubMed: 15609123].

38. Yang Y, Du Y, Luo WX, Li C, Chen Y, Cheng K, et al. Hepatitis B virus reactivation and hepatitis in gastrointestinal cancer patients after chemotherapy. Cancer Chemother Pharmacol. 2015;75(4):783-90. doi: 10.1007/s00280-015-2700-4. [PubMed: 25687988].

39. Jang JW. Hepatitis B virus reactivation in patients with hepatocellular carcinoma undergoing anti-cancer therapy. World J Gastroenterol. 2014;20(24):7675-85. doi: 10.3748/wjg.v20.i24.7675. [PubMed: 24976705].

40. Ikeda K, Shiga Y, Takahashi A, Kai T, Kimura H, Takeyama K, et al. Fatal hepatitis B virus reactivation in a chronic myeloid leukemia patient during imatinib mesylate treatment. Leuk Lymphoma. 2006;47(1):155-7. doi:10.1080/14639230500236818. [PubMed: 16321842].

41. Wang YD, Cui GH, Li M, Gowrea B, Xia J, Hu Y. Hepatitis B virus reactivation in a chronic myeloid leukemia patient treated with imatinib mesylate. Chin MedJ(Engl). 2012;125(14):2636-7. [PubMed: 22882953].

42. Dixon WG, Kezouh A, Bernatsky S, Suissa S. The influence of systemic glucocorticoid therapy upon the risk of non-serious infection in older patients with rheumatoid arthritis: a nested case-control study.Ann Rheum Dis. 2011;70(6):956-60. doi:10.1136/ard.2010.144741. [PubMed: 21285116]

43. Nobili L, Albani L, Gabrielli A, Moroncini G. Reactivation of Hepatitis B Virus Infection Associated with Anti-Tumor Necrosis Factor-a Therapy. J Antivir Antiretrovir. 2014(6):92-101.

44. Ryu HH, Lee EY, Shin K, Choi IA, Lee YJ, Yoo B, et al. Hepatitis B virus reactivation in rheumatoid arthritis and ankylosing spondylitis patients treated with anti-TNFalpha agents: a retrospective analysis of 49 cases. Clin Rheumatol. 2012;31(6):931-6. doi: 10.1007/s10067-0121960-1. [PubMed: 22349880].

45. Tamori A, Koike T, Goto H, Wakitani S, Tada M, Morikawa H, et al. Prospective study of reactivation of hepatitis $\mathrm{B}$ virus in patients with rheumatoid arthritis who received immunosuppressive therapy: evaluation of both HBsAg-positive and HBsAg-negative cohorts. J Gastroenterol. 2011;46(4):556-64. doi: 10.1007/s00535-010-0367-5. [PubMed: 21246383].

46. Lan JL, Chen YM, Hsieh TY, Chen YH, Hsieh CW, Chen DY, et al. Kinetics of viral loads and risk of hepatitis B virus reactivation in hepatitis B core antibody-positive rheumatoid arthritis patients undergoing anti-tumour necrosis factor alpha therapy. Ann Rheum Dis. 2011;70(10):1719-25. doi: 10.1136/ard.2010.148783. [PubMed: 21719446].

47. Perez-Alvarez R, Diaz-Lagares C, Garcia-Hernandez F, Lopez-Roses L, Brito-Zeron P, Perez-de-Lis M, et al. Hepatitis B virus (HBV) reactivation in patients receiving tumor necrosis factor (TNF)-targeted therapy: analysis of 257 cases. Medicine (Baltimore). 2011;90(6):359-71. doi:10.1097/MD.ob013e3182380a76. [PubMed: 22033451].

48. Pyrpasopoulou A, Douma S, Vassiliadis T, Chatzimichailidou S, Triantafyllou A, Aslanidis S. Reactivation of chronic hepatitis B virus infection following rituximab administration for rheumatoid arthritis. Rheumatol Int. 2011;31(3):403-4. doi: 10.1007/s00296-009-1202-2.
[PubMed: 19830433].

49. Salman-Monte TC, Lisbona MP, Garcia-Retortillo M, Maymo J. Reactivation of hepatitis virus $B$ infection in a patient with rheumatoid arthritis after treatment with rituximab. Reumatol Clin. 2014;10(3):196-7. doi: 10.1016/j.reuma.2013.05.011. [PubMed: 24054835].

50. Ceneli O, Ozkurt ZN, Acar K, Rota S, Aki SZ, Yegin ZA, et al. Hepatitis B-related events in autologous hematopoietic stem cell transplantation recipients. World J Gastroenterol. 2010;16(14):1765-71. [PubMed: 20380010].

51. Hammond SP, Borchelt AM, Ukomadu C, Ho VT, Baden LR, Marty FM. Hepatitis B virus reactivation following allogeneic hematopoietic stem cell transplantation. Biol Blood Marrow Transplant. 2009;15(9):1049-59. doi: 10.1016/j.bbmt.2009.05.001. [PubMed: 19660717].

52. Lin PC, Poh SB, Lee MY, Hsiao LT, Chen PM, Chiou TJ. Fatal fulminant hepatitis B after withdrawal of prophylactic lamivudine in hematopoietic stem cell transplantation patients. Int J Hematol. 2005;81(4):349-51. doi: 10.1532/IJH97.A10411. [PubMed: 15914368].

53. Uhm JE, Kim K, Lim TK, Park BB, Park S, Hong YS, et al. Changes in serologic markers of hepatitis B following autologous hematopoietic stem cell transplantation. Biol Blood Marrow Transplant. 2007;13(4):463-8. doi: 10.1016/j.bbmt.2006.11.019. [PubMed: 17382252].

54. Yoo JJ, Cho EJ, Cho YY, Lee M, Lee DH, Cho Y, et al. Efficacy of antiviral prophylaxis in HBsAg-negative, anti-HBc positive patients undergoing hematopoietic stem cell transplantation. Liver Int. 2015;35(12):2530-6. doi: 10.1111/liv.12882. [PubMed: 26053357].

55. Knoll A, Pietrzyk M, Loss M, Goetz WA, Jilg W. Solid-organ transplantation in HBsAg-negative patients with antibodies to HBV core antigen: low risk of HBV reactivation. Transplantation. 2005;79(11):1631-3. [PubMed: 15940056].

56. Mikulska M, Nicolini L, Signori A, Rivoli G, Del Bono V, Raiola AM, et al. Hepatitis B reactivation in HBsAg-negative/HBcAb-positive allogeneic haematopoietic stem cell transplant recipients: risk factors and outcome. Clin Microbiol Infect. 2014;20(10):O694-701. doi: 10.1111/1469-0691.12611. [PubMed: 24575948].

57. Kempinska A, Kwak EJ, Angel JB. Reactivation of hepatitis B infection following allogeneic bone marrow transplantation in a hepatitis Bimmune patient: case report and review of the literature. Clin Infect Dis. 2005;41(9):1277-82. doi: 10.1086/496924. [PubMed: 16206102].

58. Blanpain C, Knoop C, Delforge ML, Antoine M, Peny MO, Liesnard C, et al. Reactivation of hepatitis $B$ after transplantation in patients with pre-existing anti-hepatitis B surface antigen antibodies: report on three cases and review of the literature. Transplantation. 1998;66(7):883-6. [PubMed: 9798698].

59. Levitsky J, Doucette K, A. S. T. Infectious Diseases Community of Practice . Viral hepatitis in solid organ transplantation. Am J Transplant. 2013;13 Suppl 4:147-68. doi:10.1111/ajt.12108. [PubMed: 23465008].

60. Tomblyn M, Chiller T, Einsele H, Gress R, Sepkowitz K, Storek J, et al. Guidelines for preventing infectious complications among hematopoietic cell transplantation recipients: a global perspective. Biol Blood Marrow Transplant. 2009;15(10):1143-238. doi: 10.1016/j.bbmt.2009.06.019. [PubMed: 19747629].

61. Nakamoto S, Kanda T, Nakaseko C, Sakaida E, Ohwada C, Takeuchi $\mathrm{M}$, et al. Reactivation of hepatitis B virus in hematopoietic stem cell transplant recipients in Japan: efficacy of nucleos(t)ide analogues for prevention and treatment. Int J Mol Sci. 2014;15(11):21455-67. doi: 10.3390/ijms151121455. [PubMed: 25421241].

62. Fong TL, Di Bisceglie AM, Gerber MA, Waggoner JG, Hoofnagle JH. Persistence of hepatitis B virus DNA in the liver after loss of HBsAg in chronic hepatitis B. Hepatology. 1993;18(6):1313-8. [PubMed: 8244254].

63. Kim MK, Ahn JH, Kim SB, Im YS, Lee SI, Ahn SH, et al. Hepatitis B reactivation during adjuvant anthracycline-based chemotherapy in pa- 
tients with breast cancer: a single institution's experience. Korean J Intern Med. 2007;22(4):237-43. [PubMed: 18309681].

64. Engels EA, Cho ER, Jee SH. Hepatitis B virus infection and risk of non-Hodgkin lymphoma in South Korea: a cohort study. Lancet Oncol. 2010;11(9):827-34. doi: 10.1016/S1470-2045(10)70167-4. [PubMed: 20688564].

65. Kusumoto S, Tanaka Y, Suzuki R, Watanabe T, Nakata M, Takasaki H, et al. Monitoring of Hepatitis B Virus (HBV) DNA and Risk of HBV Reactivation in B-Cell Lymphoma: A Prospective Observational Study. Clin Infect Dis. 2015;61(5):719-29. doi: 10.1093/cid/civ344. [PubMed: 25935551].

66. Kim E, Yune S, Ha JM, Lee WJ, Hwang JW, Paik YH, et al. Hepatitis $B$ virus reactivation during anti-cancer chemotherapy in patients with past hepatitis B virus infection. Hepatogastroenterology. 2014;61(134):1704-11. [PubMed: 25436366].

67. Seto WK, Chan TS, Hwang YY, Wong DK, Fung J, Liu KS, et al. Hepatitis $B$ reactivation in patients with previous hepatitis $B$ virus exposure undergoing rituximab-containing chemotherapy for lymphoma: a prospective study. J Clin Oncol. 2014;32(33):3736-43. doi: 10.1200/JCO.2014.56.7081. [PubMed: 25287829].

68. Koo YX, Tay M, Teh YE, Teng D, Tan DS, Tan IB, et al. Risk of hepatitis $B$ virus (HBV) reactivation in hepatitis B surface antigen negative/hepatitis B core antibody positive patients receiving rituximabcontaining combination chemotherapy without routine antiviral prophylaxis. Ann Hematol. 2011;90(10):1219-23. doi: 10.1007/s00277011-1241-0. [PubMed: 21520001].

69. Mozessohn L, Chan KK, Feld JJ, Hicks LK. Hepatitis B reactivation in HBsAg-negative/HBcAb-positive patients receiving rituximab for lymphoma: a meta-analysis. J Viral Hepat. 2015;22(10):842-9. doi: 10.1111/jvh.12402. [PubMed: 25765930].

70. Yeo W, Chan PK, Zhong S, Ho WM, Steinberg JL, Tam JS, et al. Frequency of hepatitis B virus reactivation in cancer patients undergoing cytotoxic chemotherapy: a prospective study of 626 patients with identification of risk factors. J Med Virol. 2000;62(3):299-307. [PubMed: 11055239].

71. Shao W, Zhang F, Cong N, Li J, Song J. The hepatitis B virus reactivation after transarterial chemoembolization in Chinese hepatocellular carcinoma patients with low serum hepatitis B virus DNA level. Ther Clin Risk Manag. 2015;11:1367-70. doi: 10.2147/TCRM.S91618. [PubMed: 26379440].

72. Yeo W, Zee B, Zhong S, Chan PK, Wong WL, Ho WM, et al. Comprehensive analysis of risk factors associating with Hepatitis B virus (HBV) reactivation in cancer patients undergoing cytotoxic chemotherapy. Br J Cancer. 2004;90(7):1306-11. doi: 10.1038/sj.bjc.6601699. [PubMed: 15054446].

73. Borentain P, Colson P, Coso D, Bories E, Charbonnier A, Stoppa AM, et al. Clinical and virological factors associated with hepatitis B virus reactivation in $\mathrm{HBsAg}$-negative and anti-HBc antibodies-positive patients undergoing chemotherapy and/or autologous stem cell transplantation for cancer. J Viral Hepat. 2010;17(11):807-15. doi: 10.1111/j.1365-2893.2009.01239.x. [PubMed: 20002298].

74. Yeo W, Lam KC, Zee B, Chan PS, Mo FK, Ho WM, et al. Hepatitis B reactivation in patients with hepatocellular carcinoma undergoing systemic chemotherapy. Ann Oncol. 2004;15(11):1661-6. doi: 10.1093/annonc/mdh430. [PubMed: 15520068].

75. Tohme RA, Bulkow L, Homan CE, Negus S, McMahon BJ. Rates and risk factors for hepatitis $B$ reactivation in a cohort of persons in the inactive phase of chronic hepatitis B-Alaska, 2001-2010. J Clin Virol. 2013;58(2):396-400. doi: 10.1016/j.jcv.2013.08.012. [PubMed: 24001884].

76. Liang RH, Lok AS, Lai CL, Chan TK, Todd D, Chiu EK. Hepatitis B infection in patients with lymphomas. Hematol Oncol. 1990;8(5):261-70. [PubMed: 1701155].

77. Leaw SJ, Yen CJ, Huang WT, Chen TY, Su WC, Tsao CJ. Preemptive use of interferon or lamivudine for hepatitis $\mathrm{B}$ reactivation in patients with aggressive lymphoma receiving chemotherapy. Ann Hema- tol. 2004;83(5):270-5. doi: 10.1007/s00277-003-0825-8. [PubMed: 15060745].

78. Hsu C, Hsiung CA, Su IJ, Hwang WS, Wang MC, Lin SF, et al. A revisit of prophylactic lamivudine for chemotherapy-associated hepatitis $B$ reactivation in non-Hodgkin's lymphoma: a randomized trial Hepatology. 2008;47(3):844-53. doi: 10.1002/hep.22106. [PubMed 18302293].

79. Cheng AL, Hsiung CA, Su IJ, Chen PJ, Chang MC, Tsao CJ, et al. Steroidfree chemotherapy decreases risk of hepatitis B virus (HBV) reactivation in HBV-carriers with lymphoma. Hepatology. 2003;37(6):1320-8 doi: 10.1053/jhep.2003.50220. [PubMed: 12774010].

80. Lee YH, Bae SC, Song GG. Hepatitis B virus reactivation in HBsAgpositive patients with rheumatic diseases undergoing anti-tumor necrosis factor therapy or DMARDs. Int J Rheum Dis. 2013;16(5):52731. doi: 10.1111/1756-185X.12154. [PubMed: 24164839].

81. Vassilopoulos D, Apostolopoulou A, Hadziyannis E, Papatheodoridis GV, Manolakopoulos S, Koskinas J, et al. Long-term safety of anti-TNF treatment in patients with rheumatic diseases and chronic or resolved hepatitis B virus infection. Ann Rheum Dis. 2010;69(7):1352-5 doi: 10.1136/ard.2009.127233. [PubMed: 20472596].

82. Di Bisceglie AM. Hepatitis B and hepatocellular carcinoma. Hepatology. 2009;49(5 Suppl):S56-60. doi: 10.1002/hep.22962. [PubMed 19399807].

83. Gigi E, Georgiou T, Mougiou D, Boura P, Raptopoulou-Gigi M. Hepatitis $B$ reactivation in a patient with rheumatoid arthritis with antibodies to hepatitis B surface antigen treated with rituximab. Hippokratia. 2013;17(1):91-3. [PubMed: 23935355].

84. Dervite I, Hober D, Morel P. Acute hepatitis B in a patient with antibodies to hepatitis B surface antigen who was receiving rituximab. N Engl J Med. 2001;344(1):68-9. doi: 10.1056/NEJM200101043440120. [PubMed: 11187122].

85. Evens AM, Jovanovic BD, Su YC, Raisch DW, Ganger D, Belknap SM, et al. Rituximab-associated hepatitis B virus (HBV) reactivation in lymphoproliferative diseases: meta-analysis and examination of FDA safety reports. Ann Oncol. 2011;22(5):1170-80. doi: 10.1093/annonc/mdq583. [PubMed: 21115603].

86. Mitroulis I, Hatzara C, Kandili A, Hadziyannis E, Vassilopoulos D. Long-term safety of rituximab in patients with rheumatic diseases and chronic or resolved hepatitis B virus infection. Ann Rheum Dis 2013;72(2):308-10. doi: 10.1136/annrheumdis-2012-202088. [PubMed: 22930597].

87. van Vollenhoven RF, Fleischmann RM, Furst DE, Lacey S, Lehane PB Longterm Safety of Rituximab: Final Report of the Rheumatoid Arthritis Global Clinical Trial Program over 11 Years. J Rheumatol. 2015;42(10):1761-6. doi: 10.3899/jrheum.150051. [PubMed: 26276965]

88. Di Bisceglie AM, Lok AS, Martin P, Terrault N, Perrillo RP, Hoofnagle JH. Recent US Food and Drug Administration warnings on hepatitis $B$ reactivation with immune-suppressing and anticancer drugs: just the tip of the iceberg?. Hepatology. 2015;61(2):703-11. doi: 10.1002/hep.27609. [PubMed: 25412906].

89. Biondo MI, Germano V, Pietrosanti M, Canzoni M, Marignani $\mathrm{M}$, Stroffolini $\mathrm{T}$, et al. Lack of hepatitis B virus reactivation after anti-tumour necrosis factor treatment in potential occult carriers with chronic inflammatory arthropathies. Eur I Intern Med. 2014;25(5):482-4. doi: 10.1016/j.ejim.2013.11.014. [PubMed: 24495663].

90. Ballanti E, Conigliaro P, Chimenti MS, Kroegler B, Di Muzio G, Guarino $\mathrm{MD}$, et al. Use of anti-tumor necrosis factor alpha therapy in patients with concurrent rheumatoid arthritis and hepatitis B or hepatitis C: a retrospective analysis of 32 patients. Drug Dev Res. 2014;75 Suppl 1:S42-5. doi: 10.1002/ddr.21193. [PubMed: 25381975].

91. Chung SJ, Kim JK, Park MC, Park YB, Lee SK. Reactivation of hepatitis B viral infection in inactive HBsAg carriers following anti-tumor necrosis factor-alpha therapy. J Rheumatol. 2009;36(11):2416-20. doi 10.3899/jrheum.081324. [PubMed: 19797507]. 
92. Ostuni P, Botsios C, Punzi L, Sfriso P, Todesco S. Hepatitis B reactivation in a chronic hepatitis B surface antigen carrier with rheumatoid arthritis treated with infliximab and low dose methotrexate. Ann Rheum Dis. 2003;62(7):686-7. [PubMed:12810441].

93. Weinbaum CM, Mast EE, Ward JW. Recommendations for identification and public health management of persons with chronic hepatitis B virus infection. Hepatology. 2009;49(5 Suppl):S35-44. doi: 10.1002/hep.22882. [PubMed: 19399812].

94. Liaw YF, Kao JH, Piratvisuth T, Chan HL, Chien RN, Liu CJ, et al. AsianPacific consensus statement on the management of chronic hepatitis B: a 2012 update. Hepatol Int. 2012;6(3):531-61. doi: 10.1007/s12072012-9365-4. [PubMed: 26201469].

95. Liu JY, Sheng YJ, Ding XC, Tang H, Tong SW, Zhang DZ, et al. The efficacy of lamivudine prophylaxis against hepatitis $B$ reactivation in breast cancer patients undergoing chemotherapy: a meta-analysis.J Formos Med Assoc. 2015;114(2):164-73. doi: 10.1016/j.jfma.2012.10.007. [PubMed: 25678179].

96. Li H, Zhang HM, Chen LF, Chen YQ, Chen L, Ren H, et al. Prophylactic lamivudine to improve the outcome of HBsAg-positive lymphoma patients during chemotherapy: a systematic review and meta-analysis. Clin Res Hepatol Gastroenterol. 2015;39(1):80-92. doi: 10.1016/j.clinre.2014.07.010. [PubMed: 25199680].

97. Liu HL, Zhao Z, Yang H, Liu FF, Liu Q, Luo Q, et al. The effects of nucleoside analogue prophylactic treatment on $\mathrm{HBV}$ activation in $\mathrm{HBcAb}+$ patients undergoing immunosuppressive therapy. J Viral Hepat. 2013;20(9):645-9. doi:10.1111/jvh.12087. [PubMed: 23910649].

98. Chen FW, Coyle L, Jones BE, Pattullo V. Entecavir versus lamivudine for hepatitis B prophylaxis in patients with haematological disease. Liver Int. 2013;33(8):1203-10. doi: 10.1111/liv.12154. [PubMed: 23522150].

99. Huang H, Li X, Zhu J, Ye S, Zhang H, Wang W, et al. Entecavir vs lamivudine for prevention of hepatitis $B$ virus reactivation among patients with untreated diffuse large B-cell lymphoma receiving R-CHOP chemotherapy: a randomized clinical trial.JAMA. 2014;312(23):252130. doi: 10.1001/jama.2014.15704. [PubMed: 25514302].

100. Lee JH, Cho Y, Lee DH, Lee M, Yoo JJ, Choi WM, et al. Prior exposure to lamivudine increases entecavir resistance risk in chronic hepatitis B Patients without detectable lamivudine resistance. Antimicrob Agents Chemother. 2014;58(3):1730-7. doi: 10.1128/AAC.02483-13. [PubMed: 24395227].

101. Yatsuji H, Suzuki F, Sezaki H, Akuta N, Suzuki Y, Kawamura Y, et al. Low risk of adefovir resistance in lamivudine-resistant chronic hepatitis B patients treated with adefovir plus lamivudine combination therapy: two-year follow-up. J Hepatol. 2008;48(6):923-31. doi: 10.1016/j.jhep.2008.02.019. [PubMed: 18433925].

102. van Bommel F, Wunsche T, Mauss S, Reinke P, Bergk A, Schurmann D, et al. Comparison of adefovir and tenofovir in the treatment of lamivudine-resistant hepatitis B virus infection. Hepatology. 2004;40(6):1421-5. doi: 10.1002/hep.20464. [PubMed: 15565615].

103. Koskinas JS, Deutsch M, Adamidi S, Skondra M, Tampaki M, Alexopoulou A, et al. The role of tenofovir in preventing and treating hepatitis B virus (HBV) reactivation in immunosuppressed patients. A real life experience from a tertiary center. Eur J Intern Med. 2014;25(8):768-71. doi: 10.1016/j.ejim.2014.06.028. [PubMed: 25037900]. 